\title{
Civil society in the shadow of the Irish state
}

\author{
MARY P. MURPHY \\ Department of Sociology, National University of Ireland, Maynooth
}

\begin{abstract}
The dominant perception is that Irish society has responded to the current economic crisis in a relatively muted, moderate and passive fashion. How can we explain this apparent absence of political contestation or protest in Irish civil society? Various cultural and historical explanations can partially explain this apparent passivity; the approach here complements these explanations by exploring the institutional nature of the Irish state as an explanatory factor for the nature of the Irish civil society response to the crisis. Having first defined civil society and explored the scale and scope of Irish civil society, the article focuses on whether, or to what extent, the relative absence of a progressive civil society or movements can be partially attributed to the institutional nature of the Irish state. Five institutional or state-centred rationales are offered: the populist nature of Irish political parties; patterns of interest group formation; clientalism; corporatism; and state strategies to silence dissent. The impact on civil society of the increased marketisation of public goods is briefly discussed. The article argues that more critical awareness in civil society of how populist state institutions influence civil society will open up new possibilities for civil society strategies. It concludes by examining how institutions, interests and ideas might change. Society needs to develop a greater public sphere where cross-sectoral progressive alliances can demonstrate popular support for alternatives.
\end{abstract}

Key words: Irish civil society, clientalism, marketisation, public sphere, active society

\section{Introduction}

Since the current economic crisis took hold, international commentators in The Economist, The Wall Street Journal, Vanity Fair and the International Monetary Fund congratulated Irish society on its mature response to budget cuts (Lewis 2011). Back in Ireland, Hardiman (2009) and Byrne (2010) reflected on the 
relative passivity of Irish response to the crisis. Others described the Irish response as that of an 'extraordinarily moderate and passive society' (O'Brien 2011: 15) and 'not much more than a long collective whinge' (Dwyer 2010: 2). Mair (2010: 7) describes a 'passive' and 'demobilised' citizenry. The dominant narrative asserts the Irish waited to respond in a 'pencil revolution' in the 2011 General Election where they ejected Fianna Fáil ${ }^{1}$ and the Green Party from office. Cox (2010: 5) contests these assertions of passivity citing numerous examples of Irish people power to argue that the 'Irish movement experience is different, but it is not less than the western European or the Latin American'. Indeed, since 2008 pensioners, students, workers, parents and disadvantaged communities have mounted various local and national responses to austerity and cutbacks and used demonstrations, petitions, meetings, marches and creative 'spectacles of defiance' to register protest. Nonetheless, when compared to Iceland's 'Saturday Protests', Spain's 'Indignados' movement and Portugal's 'Desperate Generation' protests, a sense persists of a relative lack of overt Irish protest. This sense is captured in a 2010 Greek protest chant 'this is Greece, not Ireland, we the workers will resist' (Sheridan 2010). Even if the Irish response to the crisis has been less passive than generally asserted, questions nonetheless linger. Why has dissent and debate about alternatives had such little impact on framing the crisis, championing alternatives or registering protest? What explains the nature of the Irish response to the crisis and is it possible to imagine a different and more effective response?

The article begins by defining civil society and exploring historical and cultural explanations that might explain a relatively passive society. It maps recent evidence about the scale, scope and characteristics of Irish civil society and levels of political participation, efficacy and trust. It then asks how statecentred explanations might explain the characteristics, strategies and practices of contemporary Irish civil society. In particular it examines how populist political parties relate to civil society; how institutions of the Irish state impact on patterns of interest group formation; how clientalism and localism work to politically neutralise civil society actors; how corporatism leads to co-option; how strategies of state capture and control silence dissent and finally whether marketisation of public goods creates new challenges for Irish civil society. It concludes by exploring strategies to challenge that culture.

\section{Defining civil society}

The notion of civil society is problematic conceptually and is a contested field of meanings (Chambers and Kapstein 2006; Taylor 2006; Roginsky and Shortall 2009). The approach taken here mirrors Cohen and Arato's where civil society is defined as 'a sphere of social interaction between economy and state' (1992: ix). This stresses a Habermasian focus on the public sphere and communication (Powell and Guerin 1997: 15). Recognising civil society can work as an 
oppressive force and arguing against a romantic tendency of seeing civil society as a panacea for all, Edwards (2005:6) draws from three traditions in civil society literature (Putman's associational life, the Aristotelian tradition of a normative value of a good society and the Habermasian concept of the public sphere) to define a concept of civil society as a tripartite relationship of associational activity, normative values or ideas of a kind of good society and a public sphere in which to deliberate and negotiate those outcomes. This definition was used in Ireland by the Carnegie Inquiry into Civil Society (2007) and is also consistent with Powell and Guerin's (1997: 25) connection of civil society to generative political strategies and Powell's (2007) later argument for a 'social left'.

Polanyi makes a persuasive historical argument that at times of transformation a dialectical 'double movement' from an 'active society' works as a transformative agent capable of re-embedding an unsustainable commodified economy to meet the needs of society (Burawoy 2003). This is consistent with Gramsci's understanding of the role of civil society, both legitimating ruling hegemony, but also producing alternative hegemonies. Fox Piven (2008) demonstrates how 'power from below' has at times tamed contemporary capitalism. While avoiding an argument that progressive civil society is the answer to the unfettered power of global neoliberalism (Crouch 2011), the article asks why, given the scale of crisis, an Irish alternative or 'double movement' has been slow to emerge from Irish civil society. Buroway (2003) stresses civil society as a specific historical product of European capitalism in the late nineteenth century. The distinctive form progressive civil society takes reflects the institutional logic of capitalist arrangement in any one country. Hence, the relationship between the state and the market and the national or local political economy is crucial in determining the shape of civil society. Roseneil and Williams (2004) argue social movements are profoundly shaped by the policy direction of the governments they seek to influence, each state actively reframes civil society's political claims, policy demands and public values.

\section{Explaining Irish civil society}

There are numerous historical and cultural explanations for the nature of Irish civil society. Keane (2011) finds reason in the legacy of the crushing defeat of the 1798 rebellion and devastation of the 1840s Irish famine. Adshead and Tonge (2009: 142) identify Ireland's peripheral location, and a conservative, peasant, land-owning, rural culture as key factors influencing the political culture of Irish civil society. Dissent may be dimmed by a broader post-colonial tendency to accept authority or by the dominant Catholic Church and its promotion of deference, victimhood and internalisation of blame and anger. The power of the Irish Catholic Church enabled it to maintain a social control role at parish level and an oppressive regime in institutionalised education and industrial schools that limited Irish social and political development and the likelihood of progressive 
civil society in Ireland (Inglis 1998). Irish church and state also combined to produce a patriarchal socialisation of gender roles; women were pushed into private domestic roles and Irish public discourse remains profoundly gendered. While other Catholic Church-dominated societies appeared able to shake off this repressive legacy, Ireland facilitated continued Church control of education and neglected citizenship education (Harris 2005). O'Brien (2011) points to a continued 'weak infrastructure of dissent' in a historically legitimate Irish state. The 'safety valve' of emigration certainly helped contain civil dissent about the economic and social failures that might otherwise have challenged the legitimacy of that state; the fostering of private home ownership did likewise.

In response to colonialism, Ireland developed a nationalism informed by a 'religious-ethnic conceptualization of nation' which reinforced a political culture associated not with citizenship, but with authoritarianism, conformism and loyalty (Adshead and Tonge 2009: 147). The civil war ${ }^{2}$ political legacy meant little ideological or class divide in the historical evolution of Irish political parties and 'a lack of polarisation or ideological conflict' (Mair 2010: 2). The more recent forty years of conflict in Northern Ireland further impacted on class politics. Despite extensive early twentieth-century working- class militancy, mass action, labour activism and the socialist and trade union movement (Kostick 1996), and evidence of twentieth-century Irish labour's political struggle (McGuire 2007), over time the left in Ireland was politically marginal (O'Connor 2002) and deeply fragmented. In addition to the civil war legacy, the strong presence of an anti-socialist Catholic Church in Irish politics, the absence of a strong industrial base, the populist stances of Fianna Fáil and its capacity to appeal to the trade union movement, the Labour Party's internal weaknesses and tactical errors, all explain the under development of a large Irish left political tradition (Puirséil 2007: 308). Gallagher (1985: 92) argues that the relatively cautious and reformist nature of the Irish Labour Party reflected the dominant conservative electoral environment, an unsympathetic Church, the prevailing constitutional issues and a political culture of consensus that valued individualism over collective or structural action.

At least some of the above factors can also explain a relative weakness of progressive civil society in Ireland. But how have these historical factors had such strong legacy and why do they remain so embedded in political and civil culture? This article offers state or institutional explanations for the nature of Irish civil society and its strategies in response to crisis. Its focus is to further explain the nature of Irish civil society by exploring in more depth how it is institutionally shaped by a populist state in the historical trajectory of Irish state/society/market relationships. It demonstrates how institutions of the state embed a particular culture and variety of Irish civil society and actively frame civil society responses to the crisis. It also asks how this is changing. 


\section{Irish civil society, the evidence}

There is compelling evidence about extensive progressive civil society activity in Irish history (Acheson et al. 2004). Daly (2007) and Adshead and Tonge (2009: 139) map an 'active, large scale and wide spread' civil society. Connolly and Hourigan (2006) map the scale and breadth of social movements in Ireland, with Connolly drawing particular attention to the women's movement. Cox (2010: 6) argues that in the 1970s and 1980s Ireland saw massive rates of movement participation. Progressive civil society movements include an anticapitalist 'movement of movements', local environmental activism, gender and sexual identity activism, local and community development, equality and antipoverty activism and trade union activism (Harvey 1998; O'Connor 2002; Cox 2006; Murray 2007; Bissett 2009; Leonard 2010). Nonetheless, Meade argues 'Ireland is not exactly overburdened with radical media organisation, critical networking forums or broadly inclusive social movements' (2005: 369). What does the evidence say?

Ireland is about or above the European average on most indicators of social capital, including membership of voluntary or community associations and levels of volunteering (NESF 2003). Donoghue et al. (2006) estimated 24,000 Irish civil society associations primarily focused on the fields of development and housing, education and research, sports and recreation, social services and arts, culture and heritage. The Taskforce on Active Citizenship (2007) found both volunteering and community involvement increased over 2002-06 with one-third of adults involved in 'civic activity', compared in one in six across Europe. However, Donoghue et al. (2006) found only 18.25 per cent of that participation engaged in civil rights and advocacy. Mair (2010) found only 2 per cent of the population are members of political parties (less than the 6 per cent European average and third lowest in twenty countries in Western Europe). Voter turnout declined from 76 per cent in 1997 to 63 per cent in 2002 (the fifth lowest level of election turnout in Western Europe). Ireland is also below average for trade union density which dropped to 31 per cent at the height of the boom and is low relative to other countries (Walsh and Strobel 2009). Irish civil activity, while significant, is skewed towards sporting and volunteering activity with less advocacy, political activity and party membership, voting or union membership. For Mair (2010), this is evidence of a disengaged and passive citizenship, but the TASC Democracy Commission (an independent think-tank dedicated to combating Ireland's high level of economic inequality and ensuring that public policy has equality at its core) conclude Irish people, although disillusioned and disenchanted, are not disengaged (Harris 2005: 122).

Trust and political participation are closely related. The Taskforce on Active Citizenship (2007) reported 38 per cent of citizens as interested in politics (either 'definitely' or 'somewhat') with 54 per cent thinking they could 'influence decisions at the local level'. Fahey et al. (2005) analysed confidence in political institutions and people's propensity to participate in political activity 
and found Ireland broadly consistent with, or above European levels of activity. Table 2 shows Irish interest in participation in formal politics to be less than the European average, but Irish interest in approved and unapproved protest activity above the European average, suggesting an orientation to political contestation. Tables 3 and 4 show mixed attitudes to politics, but low levels of both personal and institutional efficacy (Garry et al. 2006: 74). Might this low esteem for Irish politics and lack of faith in political institutions explain some disengagement?

Table 1: People's propensity to become engaged in and participate in political activity

\begin{tabular}{lcc}
\hline & Ireland (\%) & Rest of Europe (\%) \\
\hline $\begin{array}{l}1 \text { Very/somewhat interested } \\
\text { in politics }\end{array}$ & 43 & 46 \\
2 Politics very/quite & 32 & 33 \\
important & 46 & 71 \\
3 Follow politics in the & & \\
news several times a & & \\
week/more & 59 & 73 \\
4 Frequently discuss & & \\
politics & 45 & 71 \\
5 Have/might help political & & \\
party or candidate & 84 & 60 \\
6 Have/might sign a \\
petition
\end{tabular}

Source: European Values Study 1999-2000 (Fahey et al. 2005: 203, adapted)

Table 2: Interest in approved and unapproved political activity

\begin{tabular}{lcc}
\hline & Ireland (\%) & Rest of Europe (\%) \\
\hline Interest in politics (1-5 in Table 1) & 45 & 56 \\
Approved political protest (6-8 in Table 1) & 63 & 58 \\
Unapproved political protest (9-10 in Table 1) & 27 & 21 \\
\hline
\end{tabular}

Source: European Values Study 1999-2000 (Fahey et al. 2005: 203, adapted) 
Table 3: Levels of efficacy: percentage of respondents agreeing with following statements

\begin{tabular}{lccc}
\hline & $\begin{array}{c}\text { Disagree } \\
(\%)\end{array}$ & $\begin{array}{c}\text { Neither } \\
(\%)\end{array}$ & $\begin{array}{c}\text { Agree } \\
(\%)\end{array}$ \\
\hline $\begin{array}{l}\text { Personal efficacy } \\
\begin{array}{l}\text { Sometimes politics and government seem } \\
\text { so complicated that a person like me cannot } \\
\text { really understand what is going on }\end{array}\end{array}$ & 33 & 61 & 27 \\
$\begin{array}{l}\text { I think I am better informed about politics } \\
\text { and government than most people }\end{array}$ & 56 & 17 & 56 \\
$\begin{array}{l}\text { System efficacy } \\
\text { The ordinary person has no influence on } \\
\text { politics }\end{array}$ & 40 & 4 & 69 \\
$\begin{array}{l}\text { It doesn't matter which political party is in } \\
\text { power , in the end things go on the same }\end{array}$ & 25 & 6 & 28 \\
$\begin{array}{l}\text { In today's world an Irish government can't } \\
\text { really influence what happens in this country }\end{array}$ & 62 & 9 & \\
\hline
\end{tabular}

Source: Irish Social and Political Attitude Survey 2002 (Garry et al. 2006: 66, adapted)

Table 4: Summary of levels of political alienation

\begin{tabular}{ll}
\hline Alienation dimension & $\%$ \\
\hline Low trust & 32 \\
Low personal efficacy & 41 \\
Low system efficacy & 29 \\
Low interest in politics & 46 \\
Low knowledge & 52 \\
\hline
\end{tabular}

Source: Irish Social and Political Attitude Survey 2002 (Garry et al.2006: 68, adapted)

\section{Explaining underdevelopment of a progressive civil society}

Fahey et al. (2005: 217) argue that political engagement is stimulated by low levels of confidence in policy outputs, but undermined by low levels of confidence in political institutions. In the 1980s and 1990s, Irish confidence in political institutions and the civil service was high relative to the rest of Europe, but recent Eurobarometer and MRBI evidence shows a crisis in public trust in political institutions with a fall in confidence levels in the government in the last half of 2008 from 46 per cent to 18 per cent and a continual decline to around 10 per cent (Hardiman 2009). The 2010 Edelman Trust Barometer shows Ireland experiencing a profound crisis of trust in the political process, the lowest in the twenty-two countries surveyed (Cahalene 2011). We might expect lack of 
confidence in policy outputs associated with an economic crisis to heighten political engagement; however, following Fahey et al. (2005), high levels of declining trust in political institutions may reduce the likelihood of such engagement and increase the likelihood of passivity. Can other institutional or state-centred explanations illuminate our understanding of these state-society relations and add to earlier explanations for the weakness of progressive Irish political forces? Acheson et al. (2004: 197) argue that the Irish state plays a key role 'in structuring the civic space in which voluntary action occurs'. State-centred explanations can run the danger of presenting the 'state' as a more coherent entity or actor than it really is, can underplay the role of society and the market and downplay the role of agency. However, they can at least partially account for some characteristics and strategies of Irish civil society. This section examines five state-centred explanations for this particular form of civil society and briefly comments on the changing relationship between state, society and market and how increased marketisation of public goods poses new challenges for civil society.

\section{The populist nature of Irish political parties}

Populism as the dominant style of Irish politics has implications for civil society. Populist political parties are characterised by their use of and capture of intermediate associations and civil society organisations. Civil society and social capital, even when strong, can be soured or contaminated by a state dominated by one political party and shaped to meet the needs of that party and state (CINEFOGO 2008). The Irish state was a creation of Irish civil society and enjoyed the legitimacy of that society (Acheson et al. 2004). The struggle for independence against the 'colonial other' created a perception of a unified society and distracted from class and other cleavages and divisions. Irish society was subsequently shaped by a weak but controlling state (Pellion 1995) and dominated by a populist political party, Fianna Fáil (FF), in a culture that emphasised solidarity, cohesion and homogeneity, but maintained a political discourse that is largely non-ideological (Mair 1992). One Party Dominant System (OPDS) literature sees the Irish experience of FF as being similar to the Indian, Italian, Japanese and Mexican experiences where one party dominated state-society relations (Suttner 2006). These OPDS cultures have in common centrist policies, patron-client relations, a tendency to conflate party and state and to reward party supporters by appointing them to public positions and a tendency towards brokerage-style politics where people deal with the state, not directly as citizens, but through party middlemen. FF's populist success forced opposition parties to try to emulate them so all the main political parties employ relatively populist language and tactics, and appeal to national and community interests over class ones (Mair 1992: 409). 'Community' becomes the language used by parties to 
express identity values to the Irish electorate and replaces concepts of active citizenship or civil society (O’Carroll 2002).

This combination of strong state legitimacy and populist political culture bred a strong, but 'sour' Irish social capital as manifested through a number of strengths, localism and strong service delivery capacity, but also manifested by an absence of conflict, debate and contestation (Kirby and Murphy 2009). This state fostered a strong dependence of wide sectors of Irish civil society which led to a complex relationship of 'antipathy and strain ... where the needs of marginalised people are secondary to political concerns' (Geoghegan and Powell 2007: 44). Contemporary 'soft populism' occurs when political contestation is dominated by personality, mass appeal and strong media presence of political leaders (Hall 1994). In the aftermath of the crisis there has been a strong stress on national unity and appeals for patriotism. This mood marginalises conflict and dissent, often at the expense of the more vulnerable.

\section{Irish state institutions and interest group formation}

The core institutional features of the Irish state manifest themselves in the characteristics, strategies and practices of civil society in contemporary Ireland. A highly centralised Irish executive cabinet dominates the bicameral parliament (the Oireachtas) consisting of Dáil Éireann and Seanad Éireann. This centralised power combined with a near permanent Fianna Fáil party in power enabled the state to maintain a particular strategy in relation to civil society (Cousins 2005: 123). The populist and incremental development of the Irish welfare state also shaped civil society. The special status of the Catholic Church and its historical role in service delivery meant a mixed welfare state. Cousins (2005) and Hardiman (1998) highlight the power of the middle class in determining the development of a tiered and divided welfare state. Fianna Fáil's populist and pragmatic approach to welfare meant an ad hoc development of contingencies for social policy where a wide range of social welfare payments differentiated the population. McCashin (2004) notes how the 1986 Commission on Social Welfare identified thirty-six types of child social welfare payments reflecting the contingency of the parent and whether they were blind, widowed, separated, unemployed, injured, etc. The combination of a contingent, divided and mixed delivery welfare state with a significant role for voluntary sector service provision produced in its mirror image, a civil society organised around defending or delivering services to these micro-population groups. That some of these subgroups were deemed more deserving than others militated against solidarity. Despite the populist rhetoric of unity, there was in practice a very fragmented and divided civil society. Cox argues that over time increased state reliance led to intense sectoral fragmentation (2010: 15). Macro distributional debate and imagination are limited when civil society is preoccupied with and organised around single-issue micro agendas. 


\section{Politically neutral civil society actors}

Does the institutional design of the Irish electoral system make an active society more or less likely? The Irish electoral system has multi-seat constituencies ranging from three to five seats decided by Proportional Representation Single Transferable Vote (PRSTV). ${ }^{3}$ Multi-seat constituencies lead to intra-party competition where politicians differentiate themselves through personal brokerage relations with the electorate. Thus, the political culture is 'localistic, clientalistic and intensely responsive' (Boyle 2005: 22) so we can expect protest to be at its strongest locally. Keane (2011: 3) argues that local politics is dominated by local vote maximisation strategies where 'local machine politics left little room for any tradition of dissent'. This culture enables civil society activists the key advantage of access to political elite, but this is mediated through brokerage relations. Such a culture is inconsistent with promoting a culture of empowerment, dissent or mobilisation. Working within such contradictory political models and ethos damages and contaminates Irish civil society actors, pushing them towards a personalist culture that encourages them to purposefully adopt a non-party political position. This leads to a type of politically neutralised and overly cordial civil society and a political culture that is an obstacle to dissenting political activity. This in turn leads not only to low levels of political party membership (Mair 2010), but the 'need' to be 'non party' can also be an excuse to self-censor party political or other political activity. ${ }^{4}$ Political neutrality extends to avoiding influencing a person's voting preference in referendums or general or local elections. It also militates against building alliances with progressive political parties, a key feature of progressive movement-building elsewhere (Silva 2009). Mair (2010: 3) laments a 'moribund political culture' symbolized by 'a lack of room for new ideas and new political styles'.

Civil society organisations feel implicit or explicit restrictions on their freedom to take political positions in national debate (Kirby and Murphy 2009). The 2010 Advocacy Initiative survey of the lobbying experience of Irish national level NGOs found that 86 per cent of respondents believe the environment for advocacy is becoming more challenging. Some 56 per cent of organisations said that they had not experienced threats because of advocacy work, but a substantial number report being threatened - or feeling threatened - because of their advocacy (Advocacy Initiative 2010: 7-10). While only one in nine NGOs reduced its advocacy due to 'external factors', instances of the state either cutting or publicly threatening to cut NGO funding reinforces the likelihood of self-censorship in wider civil society. Populism permeates local state bureaucracy. Boyle (2005) describes how $\mathrm{FÁS}^{5}$ could act, with relative immunity from criticism, as a 'mini Fianna Fail' distributing its largesse through community employment schemes to ever loyal and subservient civil society organisations. Recent controversies also highlighted the political protection afforded to public agencies such as FÁS whose policies and practices enabled private actors in the market economy to also benefit from a patronage culture (CPAG 2009). Boyle 
(2005: x) argues that critique of FÁS and dissent about its practices were rendered ineffective in an Irish political culture that is 'largely immune to research based critique'. Such a culture plays out most powerfully at a local level where organisations are more vulnerable and state-society relations more personal and localised.

\section{Co-option through corporatism}

Did the institutional design of Irish corporatism, which over the last two decades grew to incorporate a significant number of local and national civil society activists and organisations, give the state greater capacity to silence civil society? McCashin (2004: 276) notes the strategic importance FF attaches to establishing links with trade unions, voluntary organisations and community groups and describes this 'as a routine strategy of incorporation in a broad populist agenda'. While often described as corporatism, Irish Social Partnership is a different animal to continental state corporatism. Adshead and Tonge describe the 1996 incorporation of the community and voluntary sector in partnership as a 'poisoned chalice' (2009: 139). While often reflected positively as a strength of interest groups in Ireland, participation in partnership has also been analysed as a state strategy to silence ideological debate or alternative political discourse (Meade 2005). The role social partners play in achieving and maintaining consensus also serves to depoliticise distributional debate. Civil society was effectively institutionally entrapped within the confines of social partnership. As Dryzek (1996) anticipated, where groups are assimilated in the state and dominated by a problem solving approach, they may promote a policy agenda, but are less likely to have a political agenda. Servicing partnership also meant a growing disconnection between practice-based work and policy work and local and national work, less prospect of facilitating voice or participative democracy and also neutered capacity for mobilisation and protest (Gaynor 2009a).

\section{State capture and control}

Over time, civil society capacity to be an effective driver of political change has been curtailed by state strategies to control or limit the development of the sector (McCashin 2004). The 2007 Task Force on Active Citizenship worked to shape civil society more towards volunteering than a more deliberative form of active citizenship (Cronin 2009; Gaynor 2009b), thus 'depoliticizing its normative content'(Geoghegan and Powell 2007: 48). Harvey (2009) draws attention to legal, funding and organisational restructuring decisions which have curtailed civil society activity, limited advocacy, restricted groups to service delivery and cut funding for disadvantaged communities working to enable equal capacity for all to participate in civil society. Throughout the last decade there is growing critical awareness of the implications of too close a relationship with the 
state. Powell and Geoghegan (2004) found incorporation to the state a double bind for community activists. With increased pressure from the state to restrict activity to service delivery, the potential of progressive civil society to enable a politicised form of active citizenship is reduced (Gaynor 2009b; Geoghegan and Powell 2009; Kirby and Murphy 2009; Kirby and Ó Broin 2009). Cox (2010: 16-18) argues that an over focus on influencing the state led to partnership, professionalisation and sectoralisation at the expense of popular mobilisation and structural capacity to engage in disruptive activity. Carnegie (2007) highlighted erosion of the public sphere, declining engagement in formal politics and marginalisation of dissent in both the UK and Ireland. Daly (2007: 10) commented on 'heightened tensions' between state and civil society actors which pose challenges for its capacity to realise progressive outcomes.

\section{Marketisation}

Ireland has shifted towards a competition state which prioritises goals of capital and economic competitiveness over citizen and societal welfare. In this realignment towards the market, power shifts from both state and society towards indigenous and international capital (Kirby and Murphy 2009). This marketisation impacts on civil society in a number of ways. A shift to new public management practices has changed the practical working relationship between the state and civil society organisations with more use of service delivery contracts, competitive tendering and bureaucratic managerial controls (Harvey 2009). Some NGOs, more reliant on market funding conditions, have adapted their modus operandi to reflect a more business model of strategic planning. Privatisation policy has increased the range of public goods (housing, health, education, pensions and care) delivered through the market or through publicprivate partnerships (Bissett 2009). Lynch (2006) stresses the degree to which neoliberalism and marketisation of higher education challenges the degree to which education can continue to serve the public good and civil society it is challenged to build solidarity and facilitate awareness of our interdependency. Increased concentration of multinational corporations' ownership of media also weakens capacity to articulate and demonstrate dissent (Carnegie 2007). Crouch (2011) argues marketisation has moved the goalposts for civil society. Increased commodification and power of corporations mean both citizens and consumers are shifting their focus towards multinational corporations, as is evident for example in the Irish Shell to Sea campaign. ${ }^{6}$

\section{'Stupidity is doing the same thing but expecting different results'}

Civil society may not be as passive as it is perceived to be, but it has been largely ineffective in managing to promote debate about and mobilising support for alternatives. If civil society wants to increase capacity to create the good 
society, what must it do differently? Hay (2004) argues that at critical junctures of crisis the interaction of three discrete independent political variables, 'interests', 'institutions' and 'ideas', will determine the pace and direction of political transition or change. The challenge is to strengthen Irish civil society interests, develop new institutions with capacity to publicly deliberate and build support for alternative ideas. Being effective requires a highly active society and participative citizenry able to articulate the type of state and market they want.

This means civil society needs to break free from entrapment within this pervasive political culture and reduce its reliance on a populist state. Civil society actors face the challenge of reinventing themselves as interests capable of building capacity to articulate an alternative vision and developing alliances to promote that vision. The challenge for civil society is to shift the balance from working to deliver the state's objectives (increased volunteering and service delivery) and developing public spheres from where citizens can participate in shaping the good society. This has been the goal of many groups for many years and over the crisis. Despite attempts to depoliticise communities, there is evidence of attempts to empower active citizenship (Gaynor 2009b). Many networks and emerging movements share a critical capacity and analysis, are developing a new sense of solidarity and exploring relationships between progressive civil society and left politics (Dillon 2011).

Civil society actors need to take the offensive to define and shape their own vision within civil society. Instead of being trapped in state institutions that keep them in more micro problem-solving roles, Irish civil society needs to create institutions or new public spheres to mobilise public dialogue. This is consistent with calls for a 'project of projects' (Geoghegan and Powell 2007) and for 'a national conversation outside the state' (Cox 2010: 28). Daly (2007) and Silva (2009) advise working cross-sectorally to build links between largely separate spheres of civil society and accepting the inevitable tensions and contradictions between different tactics and models. This is difficult, but there is evidence of civil society attempting to mobilise around building public spheres. One attempt to do this was the Claiming Our Future ${ }^{7}$ event in Dublin's RDS on 30 October 2010 where more than 1,000 people from diverse backgrounds and sectors worked to articulate values and build progressive alliances for a more equal sustainable Ireland. Information technology-led strategies have created many new public spheres and successfully created virtual forums for debate. There is the danger, however, that new public spheres can perpetuate existing class and gender inequalities. Bua (2009: 9) warns that as long as entrenched structural inequalities remain unchallenged in modern society, new deliberative methods and modes of democracy will remain corrupted and unequal.

The failure of the Irish state to assert its own values left it subservient, firstly to the power and ideology of oppressive civil society in the form of the Catholic Church and, more recently, to the power and ideology of global capital. Irish active society, if it is to be effective, needs to shed its cloak of neutral discourse 
and acknowledge its values, ideas or ideological content. Smith (1998: 7) argues that 'political struggle does nevertheless depend in part on the ability to imagine alternative worlds'. The Irish Occupy Dame Street movement which began in October 2011 is evidence of this type of imagination and struggle in Ireland. ${ }^{8}$ Irish civil society is challenged to foster new language, to move away from internal, insular policy language and towards more accessible language used in everyday life and political discourse (Cox 2010: 21). Academics, particularly sociologists, need to enhance their public role in the battle of ideas. Marketisation of education makes this challenge all the more difficult, but also all the more necessary. Education remains the key tool through which society can challenge the production and propagation of ideas through the market-driven mainstream media (Lynch 2006).

\section{Conclusion: from where a more active society?}

Edward's (2005: 6 ) hope for civil society is that it can be a counter weight to individualism, an antidote to cynicism and a balance to state and market power. In a Polanyian perspective in a time of crisis, we expect civil society to provide alternative ideas and societal pressure to force the state to embed the economy to serve the interests of society. The Irish crisis has not triggered a societal reaction like Polanyi's 'double movement'. Culture often predates institutions, but institutions can embed culture. Low levels of confidence in political institutions may partially explain the absence of a more active response to the crisis, but Irish response to crisis also has to be understood in the shadow of a populist state where active society is institutionally trapped. Conflict, discourse and ideological debate are all discouraged in an apparently homogeneous population 'united in the national interest'. An absence of ideology and ideas, conflict and political dynamic, public discourse and solidarity manifests itself in a relatively weak progressive civil society. Over the last decade various state-initiated institutional reforms aimed at disabling and muting progressive civil society. This process has now intensified over the recession. Less NGO funding and more state control over that funding shifts the challenge for building an active society from NGOs to active citizens. Irish history and examples from Latin America show civil society can successfully shape macro national development. This is more likely to happen when progressive groups work in solidarity and avoid state and market attempts to build divisions between them.

The Irish state is a young state. A 2011 'Constitutional Convention' will focus the public mind on debates about political reform, and centenary celebrations in $2016^{9}$ and $2022^{10}$ will be occasions for national reflection. Debates about reform need to be driven by a clear sense of values and an ambition about what kind of society people want. This debate has so far been dominated by political, business, media and academic elites. How will progressive civil society influence 
this debate? Does it have ideas and alternatives? How can it make its voice heard in a way that does not perpetuate existing inequalities?

\section{Notes}

1 Fianna Fáil is one of the major Irish political parties, founded by de Valera in 1926 as a republican party. It had its roots in its anti-treaty position in the 1922-23 civil war and developed a cross-class national movement as much as a political party. A key institution, it dominated the Irish state and held power for 80 per cent of the last sixty years where it adopted a brokerage and populist style of politics (Mair 1992).

2 The Irish civil war (1922-23) followed the War of Independence when the country divided into opposing positions about accepting the Anglo Irish Treaty. The civil war legacy structured Irish politics into a pro-treaty (Fine Gael party) and antitreaty (Fianna Fáil party). This cleavage dominated constitutional politics.

3 PRSTV is an electoral system which aims to achieve Proportional Representation, through a system where the voter has a Single Transferable Vote which they allocate in order of preference to as many candidates as they wish. In multi-seat constituencies, the vote passes on in order until it elects someone.

4 The exception is some trade unions who, influenced by British civil society tradition, align themselves with left or social democratic parties.

5 FÁS (An Foras Áiseanna Saothair) is a national government agency with a regional and local office infrastructure responsible for delivering national and local training, labour market and employment services.

6 Shell to Sea is a group organised to protest against the Corrib Gas Project, directed by a consortium of companies led by Royal Dutch Shell. The proposed offshore natural gas project is the Corrib field in the north-west coastal area of Ireland. The campaign began in 2001 .

7 Claiming Our Future is an initiative of a number of non-government organisations and individuals who work together locally and nationally to promote values of equality, sustainability, accountability, solidarity and participation and to build a progressive movement for an equal, sustainable and thriving Ireland.

8 Occupy Dame Street is a people's movement, similar to Occupy Wall Street and up to 1,000 sister occupations in an evolving global solidarity movement. A non-violent leaderless resistance movement, it is a diverse people's initiative, unaffiliated with any political parties and standing against political and economic corruption and for equality and social justice.

9 The Easter Rising of Irish republicans against British rule in Ireland began on 24 April 1916 and ended 30 April 1916.

10 The Anglo-Irish Treaty was signed in January 1922 which led to the establishment of the Irish Republic and precipitated the Irish Civil War in the same year.

\section{References}

Acheson, N., B. Harvey and B.A. Williamson 2004. Two Paths, One Purpose: Voluntary Action in Ireland North and South. Dublin: Institute of Public Administration.

Adshead, M. and J. Tonge 2009. Politics in Ireland. Convergence and Divergence in a Two Policy Island. Basingstoke: Palgrave Macmillan.

Advocacy Initiative 2010. Advocacy Initiative Project Report, August 2010, Montague and Middlequarter, www.advocacyinitiative.ie/files/Advocacy_Initiative_Report. pdf march, accessed 27 October 2011. 
Bisset, J. 2009. Regeneration. Dublin: Tasc at New Island.

Boyle, N. 2005. FÁS and Active Labour Market Policy 1985-2004. Studies in Public Policy: 17. Dublin: The Policy Institute.

Bua, A. 2009. Realising Online Democracy. Compass Think Piece, www.compassonline. org, accessed 27 October 2011.

Burawoy, M. 2003. 'For a sociological Marxism: the complementary convergence of Antonio Gramsci and Karl Polanyi', Politics \& Society 31(2): 193-261.

Byrne, E. 2010. 'Should Irish citizens refuse to bail out the banks', Irish Times, 2 March 2010.

Cahalene, M. 2010. 'Trust in government and business in Ireland is the lowest in Europe according to pan-European survey' (26 January 2010), www.finfacts.ie/ irishfinancenews/article_1018896.shtml, accessed 27 October 2011.

Carnegie Trust 2007. Inquiry into the Future of Civil Society in the UK and Ireland. London: Carnegie UK Trust.

Chambers, S. and J. Kapstein 2006. 'Civil society and the state', pp. 363-82 in J. Dryzek, B. Honig and A. Philips (eds), Oxford Handbook of Political Theory. Oxford: Oxford University Press.

CINEFOGO 2008. Briefing Paper, Conference on Populism and Civil Society. Florence, EUI, 9-10 May. WP 29.

Cohen J. and A. Arato 1992. Civil Society and Political Theory. Cambridge, MA: MIT Press.

Comptroller and Auditor General (CPAG) 2009. Report 66 - Advertising and Promotion in FÁS. Dublin: Stationery Office.

Connolly, L. and N. Hourigan 2006. Social Movements and Ireland. Manchester: Manchester University Press.

Cousins, M. 2005. Explaining the Irish Welfare State. Lewiston, NY: The Edwin Mellen Press.

Cox, L. 2006. 'News from nowhere: the movements of movements in Ireland', pp. 210-29 in L. Connolly and N. Hourigan (eds), Social Movements and Ireland. Manchester: Manchester University Press.

Cox, L. 2010. 'Another world is under construction: social movement responses to inequality and crisis'. Paper presented to Equality in a time of crisis, Egalitarian World Initiative/UCD School of Social Justice UCD, Dublin, 7 May.

Cronin, M. 2009. 'Active citizenship and its discontents', pp. 62-77 in D. Ó Broin and P. Kirby (eds), Power, Dissent and Democracy: Civil Society and the State in Ireland. Dublin: A. \& A. Farmar.

Crouch, C. 2011. The Strange Non-Death of Neo-liberalism. London: Polity.

Daly, S. 2007. 'Mapping civil society in the Republic of Ireland', Community Development Journal 43 (2): 157-76.

Dillon, P. 2011. 'Left unity?', Look Left, 7 February.

Donoghue, F., G. Prizeman, A. O’Regan and V. Noël 2006. The Hidden Landscape: First Forays into Mapping Nonprofit Organisations in Ireland. Dublin: Centre for Nonprofit Management, Trinity College.

Dryzek, J.S. 1996. 'Political inclusion and the dynamics of democratization', American Political Science Review 90: 475-87.

Dwyer, D. 2010. 'The Irish are austerity stars of Europe', Irish Times, 3 March.

Edwards, M. 2005. 'Civil society', The Encyclopedia of Informal Education, www.infed. org/association/civil_society.htm, accessed 27 October 2011.

Fahey, T., B. Hayes and R. Sinnott 2005. Conflict and Consensus: A Study of Values and Attitudes in the Republic of Ireland and Northern Ireland. Dublin: Institute of Public Administration. 
Fox Piven, F. 2008. 'Can power from below change the world', American Sociological Review 73 (1): 1-14.

Gallagher, M. 1985. Political Parties in the Republic of Ireland. Manchester: Manchester University Press.

Garry, J., N. Hardiman and D. Payne 2006. Irish Social and Political Attitudes. Liverpool: Liverpool University Press.

Gaynor, N. 2009a. 'Deepening democracy within Ireland's social partnership', Irish Political Studies 24(3): 303-19.

Gaynor, N. 2009b. 'In-Active citizenship and the depoliticisation of community development in Ireland', Community Development Journal 46 (1): 9-36.

Geoghegan, M. and F. Powell 2007. 'Active citizenship, civil society and the enabling state. Political myth or democratic reality', Administration 55 (3): 31-50.

Geoghegan, M. and F. Powell 2009. 'The contested meaning of civil society', pp. 95-110 in D. Ó Broin and P. Kirby (eds), Power, Protest and Democracy, Civil society and the Irish State. Dublin: A. \& A. Farmar.

Hall, J.A. 1994. The State: Critical Concept. New York: Taylor \& Francis.

Hardiman, N. 1998. 'Inequality and representation of interests', pp. 122-55 in W. Crotty and D. Schmitt (eds), Ireland and the Politics of Change. London: Longman.

Hardiman, N. 2009. 'The impact of the crisis on the Irish political system'. Paper presented to Royal Irish Academy, Committee for International Affairs Conference, International Politics and the Global Economic Crisis, Dublin, 5 November.

Harris, C. (ed) 2005. Engaging Citizens: The Case for Democratic Renewal in Ireland; The Report of the Democracy Commission. Dublin:Tasc at New Island.

Harvey, B. 1998. A Guide to Influencing Policy in Ireland. Dublin: CPA.

Harvey, B. 2009. 'Ireland and civil society reaching the limits of dissent', pp. 25-34 in D. O'Broin and P. Kirby (eds), Power, Dissent and Democracy: Civil Society and the Irish State. Dublin: A. \& A. Farmar.

Hay, C. 2004. 'Ideas, interests and institutions in the comparative economy of great transformations', Review of International Political Economy 2(1): 204-26.

Inglis, T 1998. Moral Monopoly: The Rise and Fall of the Catholic Church in Modern Ireland. 2nd edn. Dublin: University College Dublin Press.

Keane, F. 2011. 'History that wouldn't go away, Irish Times, 5 February.

Kirby, P. and M. Murphy 2009. 'State and civil society in Ireland', pp. 143-9 in D. Ó Broin and P. Kirby (eds), Power, Protest and Democracy: Civil Society and the Irish State. Dublin: A. \& A. Farmar.

Kostick, C. 1996. Revolution in Ireland: Popular Militancy 1917-1923. Cork: Cork University Press.

Leonard, L. 2010. The Environmental Movement in Ireland. Dordrecht: Springer.

Lewis, M. 2011. 'When Irish eyes are crying', Vanity Fair, March.

Lynch, K. 2006. 'Neo-liberalism and marketisation: the implication for higher education', European Education Research Journal 5(1): 1-17.

Mair, P. 1992. 'Explaining the absence of class politics in Ireland', pp. 383-410 in J. Goldthorpe and C. Whelan (eds), The Development of Industrial Society in Ireland. Oxford: The British Academy.

Mair, P. 2010. 'Paradoxes and problems of modern Irish politics', paper presented to McGill Summer School: Reforming the Republic (July).

McCashin, A. 2004. Social Security in Ireland. Dublin: Gill \& Macmillan.

McGuire, C. 2007. Roddy Connolly and the Struggle of Socialism in Ireland. Cork: Cork University Press.

Meade, R. 2005. 'We hate it here, please let us stay! Irish social partnership and the 
community/voluntary sector's conflicted experiences of recognition', Critical Social Policy 25(3): 349-73.

Murray, M. 2007. 'Cosmopolitans versus the locals: community-based protest in the age of globalisation', Irish Journal of Sociology 16(2): 117-35.

NESF 2003. The Policy Implications of Social Capital Report No. 2. Dublin: Government Buildings.

O'Brien, D. 2011. 'Searching for the source of perpetual passivity', Irish Times, 19 February.

Ó Broin, D. and P. Kirby (eds) 2009. Power, Protest and Democracy: Civil Society and the Irish State. Dublin: A. \& A. Farmar.

O'Carroll, J.P. 2002. 'Culture lag and democratic deficit in Ireland: or, "Dat's outside de terms of d'agreement"', Community Development Journal 37(1): 10-9.

O'Connor, E. 2002. 'Labour history in other lands: Ireland', Labour/La Travail 50, www. historycooperative.org/journals/llt/50/o-connor.html, accessed 27 October 2011.

Powell, F. 2007. The Politics of Civil Society. Bristol: Policy Press.

Powell, F. and M. Geoghegan. 2004. The Politics of Community Development. Dublin: A. \& A. Farmar.

Powell, F. and D. Guerin 1997. Civil Society and Social Policy. Dublin: A. \& A. Farmar.

Pellion, M. 1995. 'Interest groups and the state', pp. 358-78 in Clancy Patrick et al. (eds), Irish Sociological Perspectives. Dublin: Institute of Public Administration.

Puirséil, N. 2007. Irish Labour Party 1922-73. Dublin: UCD Press.

Roginsky, S. and S. Shortall 2009. 'Civil society as a contested field of meanings', International Journal of Sociology and Social Policy 29(9/10): 473-87.

Roseneil, S. and F. Williams 2004. 'Introduction to special issue', Social Politics 11(2): 147-53.

Sheridan, G. 2010. 'Greece and Ireland', The Story, http://thestory.ie/2010/02/11/greeceand-ireland, accessed 1 June 2011.

Silva, E. 2009. Challenging Neoliberalism in Latin America. Cambridge: Cambridge University Press.

Smith, A.M. 1998. Laclau and Mouffe: The Radical Democratic Imaginary. London: Routledge.

Suttner, R. 2006. 'Party dominance “theory”: of what value?', Politikon 33(3): 277-97.

Taskforce on Active Citizenship 2007. Report of the Task Force on Active Citizenship. Dublin: Task Force on Active Citizenship.

Taylor, C. 2006. 'Invoking civil society', pp. 88-100 in R.E. Goodin and P. Pettit (eds), Contemporary Political Society: An Anthology. 2nd edn. Oxford: Blackwell Publishing.

Walsh, F. and E. Strobel 2009. 'Recent trends in trade union membership in Ireland', Economic and Social Review 40(1): 117-38. 